\title{
Analysis of Freedom of Information for its Effect on Society by Considering 2011, the Year of the Arab Spring \\ By Paul D. Callister ${ }^{1}$ and Dr. Kimberlee C. Everson ${ }^{2}$
}

2011, the year of the Arab Spring, presents a unique opportunity to look back and study how the relative freedom and development of information environments affect stability in nations throughout the Middle East and world. Such study raises interesting questions about whether freedom of information and speech are ultimately stabilizing influences for society in terms of loyalty, violence and political unrest—questions all the more important as societies face the onslaught of the internet, mobile devices and cell phones. Are non-democratic regimes "better off" by monopolizing and controlling the flow of information over new information channels? Are democratic societies, particularly developing democracies, more stable when the flow of information over such channels is relatively unrestricted? While these questions are not definitively answered, valuable insights into the relationship of information environments and stability are gained by the theory and empirical study advanced by this article.

On December 17, 2010, Mohamed Bouazizi, a Tunisian street vender, lit himself ablaze in protest to unfair police licensing practices and at the same time touched off a wave of protests that would come to be known as the Arab Spring. ${ }^{1}$ The effects of the events were international in scope, spreading throughout the Middle East, but those effects were not, as shall be seen, evenly distributed.

By June of 2011, regime changes had been forced upon four Middle Eastern governments:

Tunisia, Egypt, Libya, and Yemen. ${ }^{2}$ Other Middle Eastern governments escaped but confronted

${ }^{1}$ Professor of Law and Director of Library, University of Missouri-Kansas City School of Law.

${ }^{2}$ Assistant Professor, Quantitative Methods, Department of Educational Administration, Leadership, and Research, Western Kentucky University. The authors wish to give special thanks to Nancy Levit for her comments and contributions to this article. The authors also thank June Carbone for the inspiration to write this article and Erin Morrison and Zhenning Zhang for their research assistance. Mary Adams was a wonderful proofreader.

${ }^{1}$ Mohamed Bouazizi, ENCYClOPAEDIA BRITANNICA, http://www.britannica.com/EBchecked/topic/1753077/Mohamed-Bouazizi (last visited Nov. 11, 2014).

${ }^{2}$ See Tunisia's Ben Ali flees amid unrest, AlJAZEERA, Jan. 15, 2011, http://www.aljazeera.com/news/africa/2011/01/20111153616298850.html; Scott Peterson, Egypt's revolution redefines what's possible in the Arab world, CHRISTIAN SCI. MONITOR, Feb. 11, 2011, http://www.csmonitor.com/World/Middle-East/2011/0211/Egypt-s-revolution-redefines-what-s-possible-in-theArab-world; Richard Spencer, Libya: civil war breaks out as Gaddafi mounts rearguard fight, TELEGRAPH, Feb. 23, 
demonstrations. ${ }^{3}$ Many have believed or suspected there was a link to modern communication technologies and the social disruption in the Middle East. A few have found links between technologies and that disruption. ${ }^{4}$

The purpose of this paper is to examine the possibility that freedom of information is a stabilizing influence in societies. This paper will do this in two ways (I) through economic analysis and (II) through statistical analysis of the relationship of distress in a selection of states with and without large Muslim populations during 2011, the year of the Arab Spring. Part I offers a theoretical explanation, based on upon existing theory in legal literature known as Market for Loyalties Theory, of the phenomena occurring around the states' control and loss of control of their respective information environments. It also raises questions about whether this control over the information environment and instability can be measured. Part II seeks to link freedom of information to state instability in the context of Muslim countries in the year 2011. This article will conclude that there exists a moderate correlation between

2011, http://www.telegraph.co.uk/news/worldnews/africaandindianocean/libya/8344034/Libya-civil-war-breaks-outas-Gaddafi-mounts-rearguard-fight.html; Ernesto Londono and Sudarsan Raghavan, Yemeni crowds celebrate after President Ali Abdullah Saleh transfers power, flies to Saudi Arabia, WASH. Post, June 5, 2011, http://www.washingtonpost.com/world/middle-east/speculation-grows-on-yemeni-presidentscondition/2011/06/04/AGpN9xIH_story.html.

${ }^{3}$ See Frederik Richter, Protester killed in Bahrain "Day of Rage" - witnesses, REUTERs, Feb. 14, 2011, http://uk.reuters.com/article/2011/02/14/uk-bahrain-protests-idUKTRE71D1G520110214; Susanne Koelbl, 'It Will Not Stop': Syrian Uprising Continues Despite Crackdown, SPIEGEl Online InT’L, Mar. 28, 2011, http://www.spiegel.de/international/world/it-will-not-stop-syrian-uprising-continues-despite-crackdown-a753517.html; Algeria protest draws thousands, CBCNEws, Feb. 12, 2011, http://web.archive.org/web/20110512100629/http://www.cbc.ca/news/world/story/2011/02/12/algeria.html; Stephanie McCrummen, 13 killed in Iraq's 'Day of Rage' protests, WASH. Post, Feb. 25, 2011, http://www.washingtonpost.com/wp-dyn/content/article/2011/02/24/AR2011022403117.html; Thousands protest in Jordan, ALJAZEERA, Jan. 28, 2011, http://www.aljazeera.com/news/middleeast/2011/01/2011128125157509196.html; Kuwaiti stateless protest for third day, Middle East OnLine, Feb. 20, 2011, http://www.middle-east-online.com/english/?id=44476; Morocco King on holiday as people consider revolt, AFROL NEWS, Jan. 30, 2011, http://www.afrol.com/articles/37175; Harriet Sherwood, Israeli protests: 430,000 take to streets to demand social justice, GuARDIAN, Sept. 4, 2011, http://www.theguardian.com/world/2011/sep/04/israel-protests-social-justice; Sunil K. Vaidya, One dead, dozen injured as Oman protest turns ugly, GuLFNEws.COM, Feb. 27, 2011, http://gulfnews.com/news/gulf/oman/one-deaddozen-injured-as-oman-protest-turns-ugly-1.768789; Man dies after setting himself on fire in Saudi Arabia, BBC, Jan. 23, 2011, http://www.bbc.co.uk/news/world-middle-east-12260465; Sudan police clash with protesters, ALJAZEERA, Jan. 30, 2011, http://www.aljazeera.com/news/africa/2011/01/2011130131451294670.html.

${ }^{4}$ See, e.g., Philip N. Howard, et al, Opening Closed Regimes, What Was the Role of Social Media During the Arab Spring? (2011), http://pitpi.org/index.php/2011/09/11/opening-closed-regimes-what-was-the-role-ofsocial-media-during-the-arab-spring/. 
freedom of information and stability after controlling for other socio/economic variables. Furthermore that correlation is consistent with the theoretical economic analysis proffered in the first part of the article.

\section{Economic Analysis: The Market for Loyalties}

As originally conceived by Monroe Price, there is market where the medium of exchange is not cash, but loyalty. ${ }^{5}$ The major item or service for sale in this market is identity-the ideology, hopes, dreams, land claims, aspirations and sense of belonging of a people. The buyers are citizens, subjects and peoples, and the sellers are governments and power holders (political parties, revolutionaries, terrorists, and even brand names). Understanding this market is important because it offers an explanation of why governments and non-state powers regulate the control of information. ${ }^{6}$ Governments and power holders create monopolies in the market for loyalties to ensure they can get enough loyalty to guarantee service in the military, payment of taxes, political support for the regime, tolerance of corruption, and keeping talented and wealthy citizens and subjects in the country. The Market for Loyalties, as developed by Monroe Price, is set forth in Table 1.

Table 1: Description of the Market for Loylaties

\begin{tabular}{|l|l|}
\hline \multicolumn{1}{|c|}{ Economic Term } & \multicolumn{1}{c|}{ Market for Loyalties } \\
\hline Sellers & Governments and power holders \\
\hline Buyers & Citizens \\
\hline Price/currency & Loyalty \\
\hline Goods & Identity \\
\hline
\end{tabular}

\footnotetext{
${ }^{5}$ Monroe E. Price, The Market for Loyalties: Electronic Media and the Global Competition for Allegiances, 104 YALE L.J. 667, 669 (1994).

${ }^{6}$ The theory was initially developed by Monroe E. Price, to whom the author is particularly indebted. Id. at 668-70. See also Monroe E. Price, Media and Sovereignty: The Global Information Revolution and its Challenge to State Power 32-33 (2002) [hereinafter Price, Media and Sovereignty]; Monroe E. Price, Television: The Public Sphere and National Identity 67-74 (1995) [hereinafter Price, Television]; Monroe E. Price, Law, Force and the Russian Media, 13 CARdOzo ARTs \& EnT. L.J. 795, 801-802 (1995); Monroe E. Price, The Market for Loyalties and the Uses of Comparative Media Law, in BROADCASTING REFORM IN INDIA: MEDIA Law From a Global PerspeCtive 93, 93-103 (Monroe E. Price \& Stefaan G. Verhulst eds., 1998) [hereinafter BROAdCASTING Reform IN InDia]; Market for Loyalties, supra note 2, at 667-68; Monroe E. Price, The Market for Loyalties and the Uses of Comparative Media Law, 5 CARDOZO J. INT'L \& COMP. L. 445, 445-59 (1997) [hereinafter Comparative Media Law]; Monroe E. Price, The Newness of New Technologies, 22 CARDOZO L. Rev. 1885, 1895-96 (2001); Monroe E. Price, Satellite Transponders and Free Expression, 27 CARDOZO ARTs \& EnT. L.J. 1 (2009).
} 
Understanding the relationship of loyalty to "identity" is essential to understanding this market. Perhaps the most loyal of all groups are suicide bombers and terrorists-they are willing to sacrifice everything—and for what? Identity. "Camaraderie, power, status, honor, identity, purpose, . . . powerful emotional experiences, and the prospect of heavenly rewards" are listed as the diverse "output" offered by religious terrorist groups. ${ }^{7}$ Indeed, "ideology is not the only, or even the most important, factor in an individual's decision to join. [O]peratives are often more interested in adopting a new identity than in supporting a terrorist group's stated goals." ${ }^{8}$ Indeed as terrorist researcher and author Jessica Stern notes, "Finding an identity with dignity is absolutely key" to the motives of terrorists. ${ }^{9}$ The message of identity may consist of a party platform, ideology, or national ideals and aspirations. It may be as ephemeral as the hope for a better future or as concrete as the desire for a national homeland. Identity is valuable to buyers as it contains both the legacy of their past history and the promise of their dreams for the future (whether it is for wealth, a better life, or memorialization as a martyr).

Loyalty is the "coin of the realm." It is how identity is paid for by citizens and subjects, the buyers of the market for loyalties.

The consumer "pays" for one set of identities or another in several ways that, together we call "loyalty" or "citizenship." Payment, however, is not expressed in the ordinary coin of the realm. It includes not only compliance with tax obligations, but also obedience to laws, readiness to fight in armed services, or even continued residence within a country. ${ }^{10}$ Loyalty then is price in any price and quantity of goods (PxQ) analysis.

${ }^{7}$ Laurence R. Iannaccone, The Market for Martyrs 8, 16 (Mercatus Center, George Mason University, Global Prosperity initiative, Working Paper No. 35, 2003).

${ }^{8}$ Jessica Stern, 5 Myths About Who Becomes a Terrorist, WASH. Post, Jan.10, 2010.

${ }^{9}$ Jessica Stern, A Powerful Tool to Prevent Future Terror, TEDxAmsterdamWomen 2011 (8:28-9:13), at http://www.youtube.com/embed/om287FShCsg.

${ }^{10}$ Monroe E. Price, Market for Loyalties: Electronic Media and the Global Competition for Allegiances, 104 YALE L. J. 667, 669-70 (1994-95). 
All other factors being equal, when monopoly forces are removed from the market, the price (in this case loyalty) slides down the economic demand curve to a point of stabilization as dictated by a competitive market. New producers of identity enter the market and offer it for less price in terms of loyalty. An example might be the effect of punk rock on the former Soviet Union. Being a punk rocker did not demand military service or taxes, but it did demand loyalty in dress and hair style, commitment to certain music, and in some cases devotion to anarchism. Loyalty that would have gone to being a model Soviet citizen was now going to punk rock. See Figure 1 below, which illustrates the societal phenomenon of loyalty price dropping. While the price may be stabilizing in the loyalty market, the effect is anything but-loyalty levels necessary for military service, good citizenship, tolerance of corruption, adherence to a political party, and even staying in the country, drop. There is a destabilizing effect from loss of monopoly or oligopoly control over the market for loyalties. This is why autocratic and oligarchic forms of government seek to control information flow-without it they cannot sustain the levels of loyalty necessary to stay in power and run the country. An example is North Korea, which issues radios and TVs pre-wired to government broadcast stations. ${ }^{11}$

${ }^{11}$ North Korea's tightly controlled media, BBC, Dec. 19, 2011, http://www.bbc.com/news/world-asiapacific-16255126. 


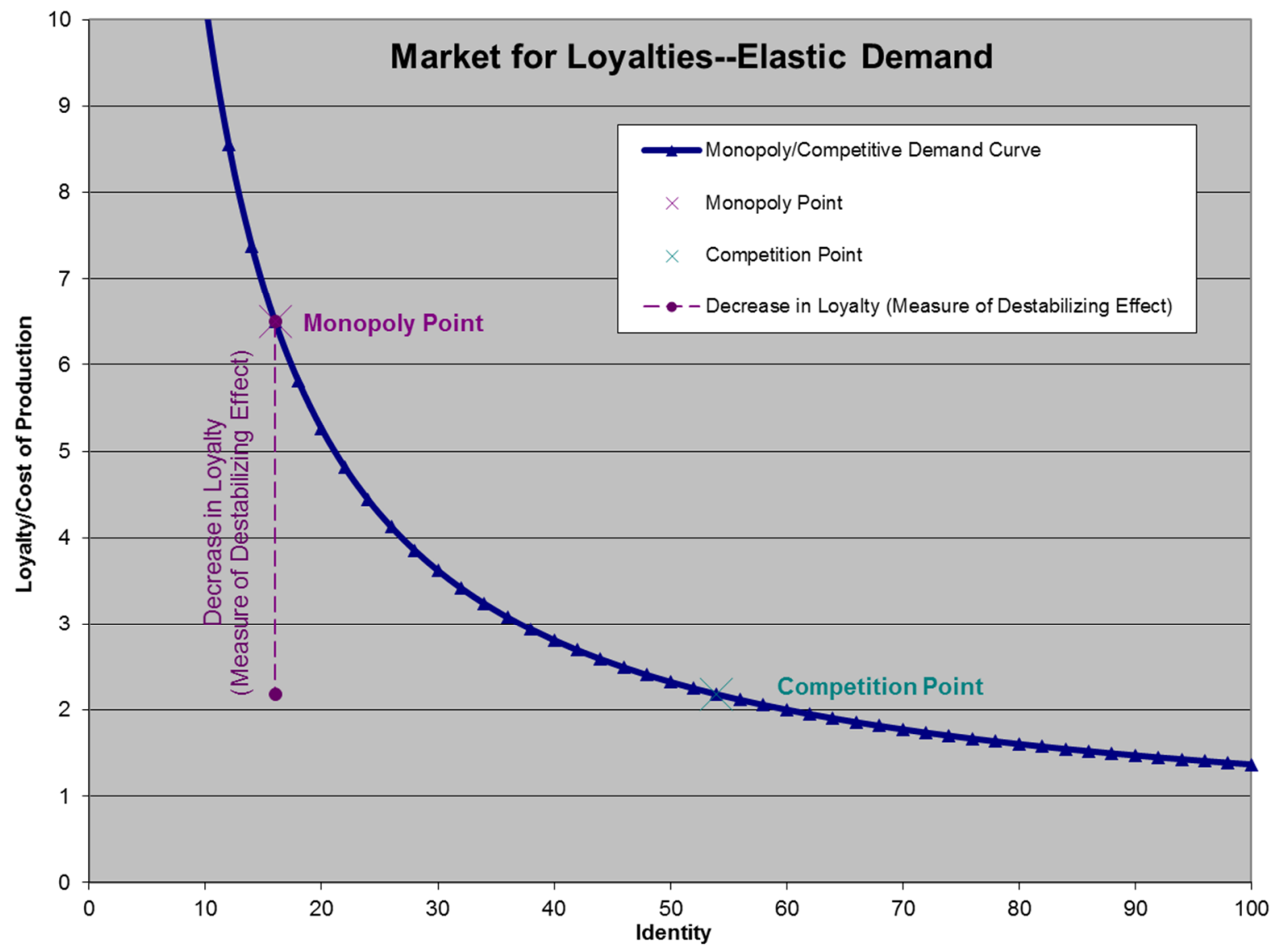

Figure 1: Demand curve illustrating the drop in loyalty in the market between the monopoly and competition points

In Figure 1 there has been a drop in price (a drop in loyalty). However, it is an oversimplification to say that the size of the vertical drop is what determines the total instability at a societal level. Rather a geometric calculation is performed based on the area of price/loyalty and goods/identity. 


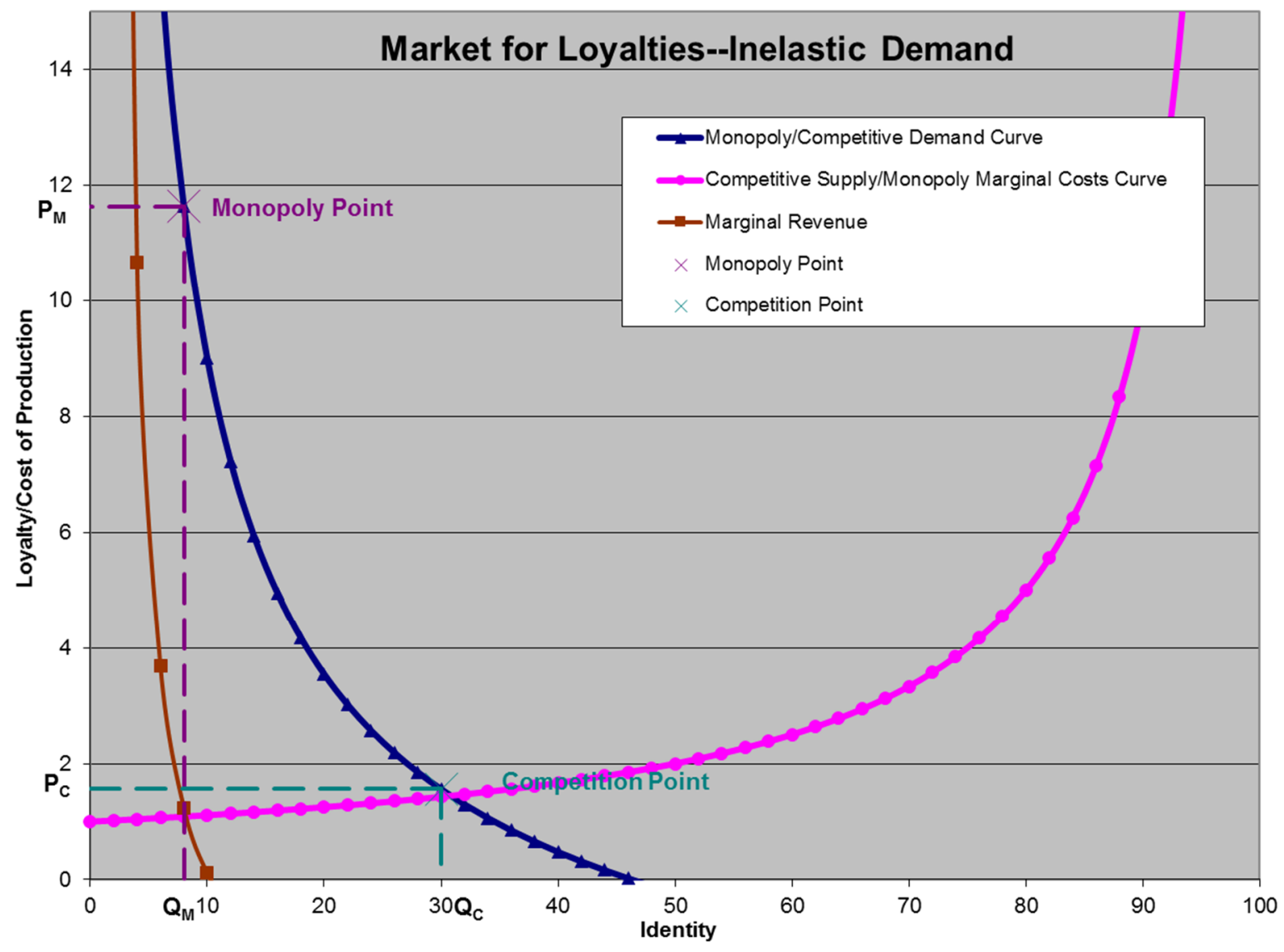

Figure 2: Graph illustrating use of $\mathrm{P} \times \mathrm{Q}$ analysis at monopoly and competition points to test for elasticity

To correctly do the analysis on a societal level, it is the comparison of the two areas $\mathrm{P}_{\mathrm{M}} \times \mathrm{Q}_{\mathrm{M}}$ (Price times Quantity at the Monopoly Point) and $\mathrm{P}_{\mathrm{C}} \times \mathrm{Q}_{\mathrm{C}}$ (Price times Quantity at Competition Point) that determines whether the market is inelastic and unstable. See Figure 2. The real question is whether there is less overall loyalty in the market for a particular society and that comparison is based upon a two dimensional figure $(\mathrm{P} \times \mathrm{Q})$.

The sizes of the two areas (one for the monopoly point and the other for the competition point) are determined, in turn, by the shape of the demand curve. Interestingly, the shape of the curve is determined by the presence of "substitute goods" in the market—for instance in the absence of internet access points in the market, radios and televisions stations can serve as substitutes, providing alternative 
channels for information. ${ }^{12}$ The more channels there are for information, the flatter (or in economic terms, the more elastic) the demand curve and the less of an impact the loss of monopoly control has on instability in the market for loyalties. See, for example, Figure 3. By way of analogy, the demand curve for motorcycles might be relatively elastic if there were plenty of inexpensive small cars (such as the British three wheel Reliant) and motorized bicycles ("mopeds") also available in the market.

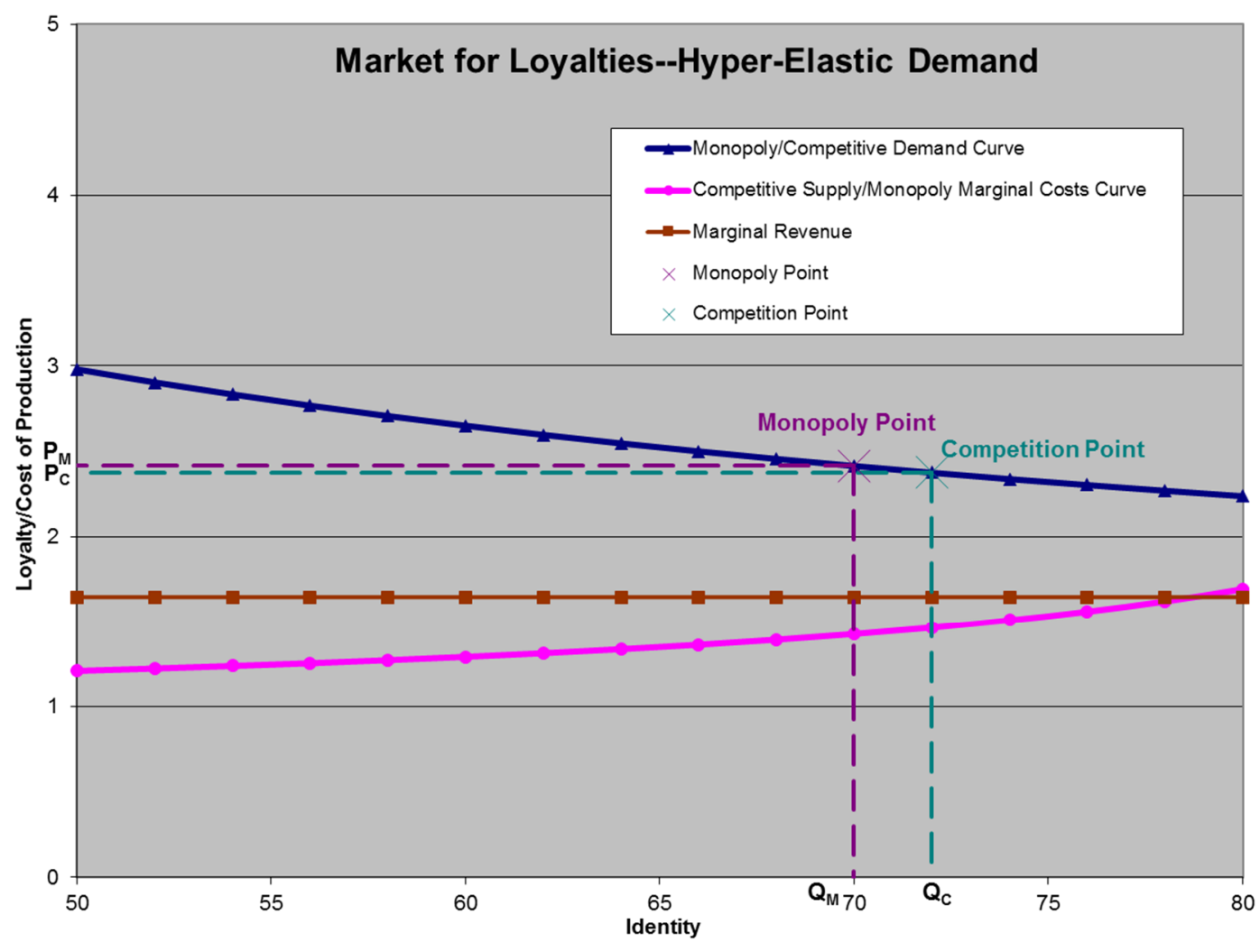

Figure 3: Hyper-elastic demand curve illustrated with $\mathrm{P} \times \mathrm{Q}$ analysis at monopoly and competition points

Market for Loyalties predicts that countries with many forms of substitute goods—identities streaming from a broad array of information channels—-books, movies, radio, etc.—will have a flatter demand curve, and hence the appearance of new information technologies, with lack of central control, will have less significant consequences in the market for loyalties. ${ }^{13}$ Ultimately, in a market with many (1998).

${ }^{12}$ See Marco Fanno, The Elasticity of Demand of Substitute Good, 3 ITALIAN ECON. PAPERS 99, 115

${ }^{13}$ See Paul D. Callister, Identity and Market for Loyalties Theories: The Case for Free Information Flow in Insurgent Iraq, 25 ST. LOUIS U. PUB. L. REV. 123, 137-38 (2006). 
substitute goods, the disruption of a new entrant grows infinitesimally small. ${ }^{14}$ "Hence, a state in which a diversity of identities flourishes is a supremely stable one, at least mathematically, with respect to the instability caused by the introduction of new identities." 15 This means that the effect of a new political newspaper, radio station, web site, etc. in the United States may be relatively inconsequential with respect to diminishment of loyalties in the market, especially compared to the impact of a new media source in a country like pre-invasion Iraq or North Korea.

This analysis assumes that diverse technologies will produce diverse messages of identity, which is one of the "goods" referred to in Market for Loyalties analysis. This may not always be the case, since it is theoretically possible for some group to seize all of the channels of communication and wield them into a single message, but common experience tells us, at least in the West, that the different information technologies diversify the messages of identity streaming into the market for loyalties. For example, the arrival of blogging and Twitter news feeds has not consolidated news into a single viewpoint, but diversified the points of view. Indeed, the phenomena of citizen journalism has facilitated diversity of

14. It might even be surmised in mathematical expressions.

$$
i=f\left(\frac{k}{p}\right)
$$

"where ' $\mathrm{i}$ ' is the instability, ' $\mathrm{k}$ ' represents the level of new competing identities being introduced, and 'p' is the penetration of previously competing identities, or substitutes, into the market." Paul D. Callister, The Internet, Regulation and the Market for Loyalties: An Economic Analysis of Transborder Information Flow, 2002 U. ILL. J.L. TECH \& POL'Y 59, 96-97. Eventually, in a state that opens itself to competing identities, if "p" were to approach infinity, the level of disturbance will grow infinitesimally small (at least with respect to the instability caused solely by the introduction of new identities):

$$
\lim _{p \rightarrow \infty}\left(\frac{k}{p}\right)=0
$$

It would not be correct to state:

$$
\lim _{p \rightarrow \infty} f\left(\frac{k}{p}\right)=0
$$

This is because a portion of the formula, namely the other factors which impact elasticity and instability, are unknown. All that is known is that the instability resulting from the introduction of new identities will approach zero if, in theory only, the number of previously introduced identities approaches infinity.

15. Id. at 97 n.178. 
viewpoints. ${ }^{16}$ Thus, the more information technology channels, the more messages, and the flatter the demand curve-which ultimately means less disruption whenever a new message of identity or information technology enters the market.

At the same time as a loss of control over information may be occurring, it would seem that suppliers requiring the least sacrifice—in terms of loyalty price-would win the most followers. The market should be settling, with all but the former autocratic power becoming comfortable with this new state of affairs. However, other forces operate to keep loyalty prices so high that opposition groups still can find followers willing to commit violence and even act as suicide bombers. The reasons for this are manifold. While loyalty prices should drop after removal of monopoly control, there may be new buyers in the market—disenfranchised peoples who long for identity. After the invasion of Iraq, such is the case with disenfranchised Shiites, Kurds, and the marsh dwellers of the south. They increased demand rather than lessened it. In a sense, countries with comparatively large numbers of jobless or underemployed young people, who represent new buyers in the market, may see loyalty prices spike upward, even as informational controls are lessened because the same forces that have liberated information have also liberated new buyers into the market. ${ }^{17}$ The opening of information channels is accompanied by violence. The loyalty price remained high because demand for identity was high. In such markets, new identities, such as being a martyr, with high loyalty prices may compete and attract followers because there simply is not enough identity available in the market.

Other factors such as tribalism can operate to create a sort of retail/wholesale market in which the tribes act as middlemen who have entered into exclusive dealing relationships with the central government or opposition groups. ${ }^{18}$ The transaction costs for leaving the tribe (death, shunning, etc.) are

${ }^{16}$ See Serena Carpenter, Source Diversity in U.S. Online Citizen Journalism and Online Newspaper Articles (paper at International Symposium on Online Journalism, April 5, 2008), https://online.journalism.utexas.edu/2008/papers/OnlineCitizenJournalism_Carpenter.pdf. "Overall, online newspaper journalists were more likely to incorporate a greater number of sources . . and a greater diversity of viewpoints." Id. at 2.

${ }^{17}$ See discussion of "marginal consumers," Callister, supra note 8, at 139-40.

${ }^{18}$ See id. at $140-146$. 
so high that the whole arrangement actually works to keep loyalty prices high. ${ }^{19}$ This was also the case in Iraq after the fall of Saddam Hussein — tribalism acted to keep loyalty prices high. ${ }^{20}$ So while removing controls over information flow should lead to a drop in the loyalty commanded by the previous power-in being, other forces such as new buyers in the market and tribalism may cause loyalty prices to remain high, even high enough to facilitate suicide bombings (perhaps the ultimate form of loyalty in this analysis).

Within the context of freedom, it would seem that freedom of information flow is desirable and that it would fall within the scope of fundamental human rights, such as in the Universal Declaration of Human Rights. ${ }^{21}$ A cold fact remains, however, from a market analysis, that the removal of censorship and controls over information flow can lead to destabilizing effects from either a radical drop in the loyalty price or an increase in demand brought about by new entrants into the market place.

So far this is only theorizing. The question presents itself: what evidence is there that freedom of information is stabilizing or destabilizing to the state? To answer that, we move from economics to statistics.

${ }^{19}$ See e.g., Rajiv Chandrasekaran, Iraqi Wild Card: Tribal Loyalties Hard to Predict, WASH. Post, Jan. 19, 2003, at A1. To betray one's tribe would have serious repercussions. In fact, when [Saddam] Hussein's sons-in-law returned to Iraq from Jordan, after betraying secrets about Iraqi weapon's program, they were killed, not by "police or the military, but [by] members of their own tribe seeking to redeem the family's honor." Id.

${ }^{20}$ See discussion of "Wholesale and Retail Markets" Callister, supra note 8, at 140-45.

${ }^{21}$ United Nations, The Universal Declaration of Human Rights, art. 19, http://www.un.org/en/documents/udhr/ (last visited Dec. 9, 2013). 


\section{Statistical Analysis of Information Flow and State Instability in Countries During 2011, the Year of the Arab Spring}

The idea is to see if there is any evidence (or correlations) that states with more freedom of access to information were better off (at least with respect to state destabilization) than their counterparts during the events that made up the Arab Spring. To do this, the information environments and relative stability of a wide swath of Muslim countries were studied, including countries that had large but not predominantly Muslim populations, like India and the Philippines. Furthermore, to properly scale measurements, countries and regions without significant Muslim populations were studied. For example, the analysis below evaluated Japan, which happened to lead in book titles published, and Hong Kong, which led in films produced.

\section{Method}

This correlational study is an examination of the relationship between freedom of information access (as suggested by greater channels of information technology) and state destabilization (defined in terms of an index measuring demonstrations, protests and violence) during the year of the Arab Spring, 2011 in a sample of selected countries. The intention was to determine whether countries without monopoly control over their information environments were better off than their counterparts during the events that made up the Arab Spring, at least with respect destabilization. While the study is primarily descriptive in nature, it is also intended that cautious inferences might be made to countries beyond those selected in the sample or to periods of time beyond the year of data collection, 2011.

\section{Sample}

Data was collected from a purposefully selected sample of 26 countries, intended to include countries with both highly controlled information environments and comparison countries that allow their citizens more free access to information. The sample was chosen to include both Muslim and nonMuslim dominant countries; however, Muslim-dominant countries were included at a higher rate due to 
their tendency to more strictly control their information environments. The countries included in the study are listed in Table Error! Main Document Only. in the footnote below. ${ }^{22}$

\section{Measures}

To empirically examine the relationship between freedom of information access and state destabilization, both constructs first needed to be measured. It was theorized that an average of normalized versions of Thomson Reuters Westlaw's Demonstrations and Protests (DP) and Violence or Civil War (VC) indices (described below) would serve as a reasonable proxy for the construct of state destabilization because they illustrate citizens in acts of disloyalty—demonstrating, committing acts of violence, inciting civil war, etc.

To measure state instability, and create the DP and VC indexes, the following method was devised:

- Using Thomson Reuters Westlaw create a "Demonstrations and Protest" (DP) Index for 26 countries:

- Search number of articles with the country name in the title for 2011.

○ Of those, search number of articles containing "demonstration" or "protest" or "riot."

${ }^{22}$ Table Error! Main Document Only.: Countries Studied

\begin{tabular}{|l|l|l|}
\hline Algeria* & Kuwait* & Saudi Arabia* \\
\hline Australia & Japan & Singapore \\
\hline Bahrain* & Jordan* & Sudan* \\
\hline China & Libya* & Syria* \\
\hline Egypt* & Malaysia* & Thailand* \\
\hline Hong Kong & Morocco* & Tunisia* \\
\hline India* & Oman* & Turkey* \\
\hline Indonesia* & Pakistan* & Yemen* \\
\hline Iran* & Philippines* & *Significant Muslim populations \\
\hline
\end{tabular}


- Subtract false positives in first 20 hits to create a multiplier to determine the number of articles to be finally counted.

- Normalize the scores by population and adjust the highest score to a 1.0 and the lowest to 0.0 with all other scores adjusted according to their respective relationships.

- Using Thomson Reuters Westlaw create a "Violence or Civil War" (VC) Index for 24 countries

- Search number of articles with the country name in the title for 2011.

O Of those articles, search the number of articles containing the following in the results: (SHOOT! OR SHOT OR BOMB! OR INSURGEN! OR TERROR! OR REBEL "CIVIL WAR" OR KILL! OR FIGHT! OR ATTACK! OR KIDNAP! \% TEAM \% FOOTBALL $\%$ CRICKET).

- Normalize the scores by population and adjust the highest score to a 1.0 and the lowest to 0.0 with all other scores adjusted according to their respective relationships.

- Combine the DP and VC scores by averaging them into a "DPVC" index

The combined results were once again normalized adjusting the highest score to a 1.0 and the lowest to 0.0 with all other scores adjusted according to their respective relationships. The DVPC index for the countries in the study are displayed in Table Error! Main Document Only. in the footnote below. $^{23}$

${ }^{23}$ Table Error! Main Document Only.: Countries Ranked by the Demonstrations, Protests, Violence, and Civil War (DPVC) Index

\begin{tabular}{|c|c|c|c|c|c|c|c|c|c|c|c|c|c|c|c|c|c|c|c|c|c|c|c|c|c|c|}
\hline & 产 & 营 & 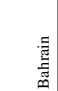 & 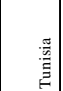 & 商 & 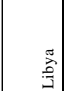 & 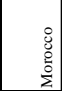 & 然 & 厗 & | & 犃 & 密 & 竎 & 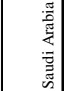 & 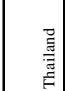 & 旁 & 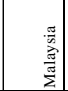 & 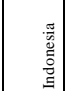 & 旁 & 焉 & 舀 & 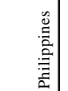 & 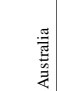 & 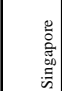 & 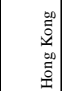 & 惑 \\
\hline 它 & 1.0000 & 0.9008 & 0.7421 & 0.5832 & 0.5193 & \begin{tabular}{|l} 
\\
\end{tabular} & \begin{tabular}{|l}
0.3834 \\
\end{tabular} & 0.3617 & 0.3040 & 0.2542 & 0.2419 & \begin{tabular}{|l}
0.1702 \\
\end{tabular} & 0.1620 & 0.1547 & $\mid 0.1166$ & \begin{tabular}{|l}
0.0997 \\
\end{tabular} & 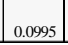 & \begin{tabular}{|l|}
0.0957 \\
\end{tabular} & 0.0899 & \begin{tabular}{|l|l|} 
\\
\end{tabular} & \begin{tabular}{|l}
0.0686 \\
\end{tabular} & 0.0530 & 0.0157 & \begin{tabular}{|l}
0.0076 \\
\end{tabular} & \begin{tabular}{|l}
0.0067 \\
\end{tabular} & \\
\hline
\end{tabular}


Initial analyses revealed that the relationship between the DPVC and the other variables of interest was non-linear (curved) and the distribution of the DPVC was skewed right. This problem was resolved by taking the natural logarithm of the DPVC before analysis. For simplicity, this logarithm of the DPVC is referred to as $L D P V C$ in this paper.

Freedom of information access was more challenging to measure because it encompasses many factors (e.g., the availability of books, internet access, cell phone usage). When several variables jointly measure one construct, one possible approach is examine each variable's impact on the outcome of interest independently, although inter-correlations among these related variables can make interpretation challenging. Another approach is to combine the measures into one overall index or variable. This can be done either by averaging the items or by creating a weighted score based on the theorized or empirically derived relevance of each variable. Averaging the items requires the assumption that all items are equally important in measuring information access. The process of creating a weighted score, however, requires either more substantive theory than we currently have available or a larger sample of countries than is realistically obtainable for the desired variables. Thus, for this study, we examined both the relationship of individual variables to the LDPVC and the relationship of the average to the LDPVC. This study includes the following twelve indicators of freedom of information access, ${ }^{24}$ each normalized onto a $[0,1]$ scale. These variables, along with their values for each country, are listed below. ${ }^{25}$ These

${ }^{24}$ For literacy rate, phone lines, cell phones, radio stations, TV stations, and Internet users, see CIA WoRLD FАСТВООК (online 2010), available at https://archive.org/stream/theciaworldfactb35830gut/35830.txt (last visited Sept. 23, 2014). For number of newspaper dailies and newspaper circulation, see The Press Reference, http://www.pressreference.com/ (last visited Sept. 23, 2014). For book titles, searches were conducted of OCLC's catalog for titles published between 2000 and 2009 in any city in the country with over one million inhabitants. If a country lacked any city with over one million inhabitants then its largest city was used. For films produced, see UNESCO Institute of Statistics, http://data.uis.unesco.org/ (CULTURE >Feature Films) (last visited Sept. 23, 2014). For public libraries, see IFLA World Report 2010, http://www.ifla-world-report.org (last visited Sept. 23, 2014). For the Freedom of the Press Index, see Freedom House, Freedom of the Press 2010, http://freedomhouse.org/sites/default/files/FOTP2010--Final\%20Booklet_5May.pdf (last visited Sept. 24, 2014).

${ }^{25}$ Table Error! Main Document Only.: Countries by Their Information Environment Factors (Normalized 1-0)

\begin{tabular}{|c|c|c|c|c|c|c|c|c|c|c|c|c|}
\hline 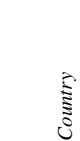 & & 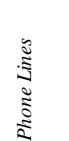 & 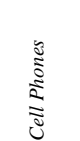 & 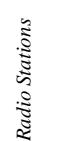 & 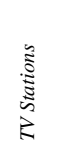 & 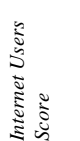 & 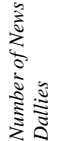 & 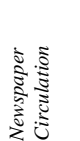 & 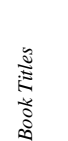 & 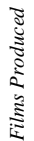 & 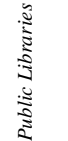 & 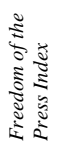 \\
\hline Algeria & 0.4073 & 0.1223 & 0.4099 & 0.0318 & 0.0023 & 0.1369 & 0.0464 & 0.052 & 0.0016 & & 0.0329 & 0.411 \\
\hline
\end{tabular}


indicators, of course, are to some degree representative of economic and industrial development, and not simply economic freedom. We remove much of the variance attributable to development for these indicators by controlling for the confounding factor, GDP. However, inferences about what the indicators represent should be made cautiously.

A further consideration is that many of these freedom of information access variables are highly correlated with other variables that predict state destabilization, such as the average age of the population. A statistically significant and large correlation between a freedom of information access variable such as cell phone usage, for example, may simply be attributable to the fact that cell phone users tend to be young and acts of violence within a country are more common among the young. Similarly, the

\begin{tabular}{|c|c|c|c|c|c|c|c|c|c|c|c|c|}
\hline Australia & 1 & 0.7084 & 0.4987 & 1 & 0.5888 & 0.8978 & 0.2638 & 0.2605 & 0.5455 & 0.1809 & 1 & 0.9863 \\
\hline Bahrain & 0.3564 & 0.5449 & 1 & 0.2325 & 0.6613 & 1 & 1 & 0.6026 & 0.0439 & 0.1884 & 0.0951 & 0.3151 \\
\hline China & 0.8493 & 0.4049 & 0.2252 & 0.0089 & 0.2988 & 0.3532 & 0.0703 & 0.1336 & 0.0566 & 0.0352 & 0.5587 & 0.137 \\
\hline Egypt & 0.4379 & 0.2135 & 0.2820 & 0.0154 & 0.142 & 0.2252 & 0.0039 & 0.0465 & 0.0157 & 0.1019 & 0.0076 & 0.4658 \\
\hline Hong Kong & 0.888 & 1 & 0.7939 & 0.061 & 0.9501 & 0.7767 & 0.7935 & 0.376 & 0.5158 & 1 & 0.1512 & 0.8356 \\
\hline India & 0.2261 & 0.0475 & 0.2242 & - & 0.0508 & 0.0594 & 0.1783 & 0.088 & 0.014 & 0.1293 & 0.5442 & 0.8356 \\
\hline Indonesia & 0.8248 & 0.2333 & 0.2659 & 0.1086 & 0.019 & 0.1225 & 0.4241 & 0.0354 & 0.0254 & 0.0343 & 0.0923 & 0.5753 \\
\hline Iran & 0.5519 & 0.566 & 0.2797 & 0.0286 & 0.0365 & 0.48 & 0.2586 & 0.03 & 0.0206 & 0.047 & 0.7289 & 0.0685 \\
\hline Japan & 1 & 0.5905 & 0.3901 & 0.0821 & 0.1972 & 0.8864 & 0.0845 & 1 & 1 & 0.4572 & 0.3493 & 1 \\
\hline Jordan & 0.8147 & 0.1286 & 0.4061 & 0.1633 & 0.4158 & 0.2947 & 0.0559 & 0.0989 & 0.1779 & 0.0651 & 0.2984 & 0.4247 \\
\hline Kuwait & 0.8839 & 0.3331 & 0.6294 & 0.0161 & 0.346 & 0.4368 & 0.4283 & 0.3053 & - & - & 0.3685 & 0.5342 \\
\hline Libya & 0.666 & 0.2854 & 0.3248 & 0.1121 & 0.221 & 0.0428 & 0.0552 & 0.0234 & 0.0063 & - & 0.0076 & - \\
\hline Malaysia & 0.7902 & 0.2549 & 0.4734 & 0.5477 & 0.3761 & 0.6728 & 0.133 & 0.1753 & 0.1117 & 0.1229 & 0.6988 & 0.411 \\
\hline Morocco & 0.0489 & - & - & 0.056 & 0.1283 & 0.3623 & 0.0728 & 0.0199 & 0.0231 & 0.0264 & 0.2685 & 0.3836 \\
\hline Oman & 0.6415 & 0.1676 & 0.6039 & 0.159 & 0.5328 & 0.552 & 0.2316 & 0.0516 & 0.0101 & 0.0468 & 0.0275 & 0.3151 \\
\hline Pakistan & - & 0.0331 & 0.2180 & 0.0097 & 0.005 & 0.1073 & 0.1758 & 0.0763 & 0.0063 & 0.0136 & 0.0296 & 0.4521 \\
\hline Philippines & 0.8697 & 0.0654 & 0.3106 & 0.3506 & 0.3008 & 0.3242 & 0.0806 & 0.1174 & 0.0212 & 0.0904 & 0.1588 & 0.6301 \\
\hline Saudi Arabia & 0.5886 & 0.3076 & 0.9185 & 0.1099 & 0.6275 & 0.4794 & 0.0437 & 0.0768 & 0.014 & 0.0122 & 0 & 0.1507 \\
\hline Singapore & 0.8676 & 0.6655 & 0.6420 & 0.1349 & 0.0178 & 0.8821 & 0.2717 & 0.5904 & 0.9985 & 0.2366 & 0.0653 & 0.3562 \\
\hline Sudan & 0.2281 & 0.01 & 0.1143 & 0.0019 & - & 0.0902 & 0.0403 & - & 0.0014 & - & 0.003 & 0.2466 \\
\hline Syria & 0.6049 & 0.2921 & 0.1577 & 0.0179 & 0.2365 & 0.1849 & - & 0.1044 & 0.01 & 0.0063 & 0.1589 & 0.1507 \\
\hline Thailand & 0.8697 & 0.1737 & 0.5543 & 0.2892 & 0.196 & 0.2817 & 0.0411 & 0.3153 & 0.0244 & 0.0953 & 0.4473 & 0.4932 \\
\hline Tunisia & 0.4969 & 0.201 & 0.3975 & 0.1491 & 0.2949 & 0.3737 & 0.0961 & 0.0373 & 0.0493 & 0.0263 & 0.497 & 0.1233 \\
\hline Turkey & 0.7637 & 0.357 & 0.3409 & 0.0497 & 1 & 0.5012 & 0.928 & 0.0936 & 0.1494 & 0.0625 & 0.2101 & 0.589 \\
\hline Yemen & 0.4196 & 0.0678 & 0.1166 & 0.0042 & 0.0073 & - & 0.0095 & 0.0064 & 0.0002 & - & - & 0.1918 \\
\hline
\end{tabular}


correlation between phone lines, newspapers, or films and violence may be simply an artifact of increased wealth leading to a desire for more access to goods, and thus more unrest and violence. It is also possible that the connection between information access and instability is an indirect result of the relationship of both variables with increased democracy, or is moderated by unemployment related stress. In other words, the correlation between the LDPVC and the access variables may be only spurious if potential confounding variables are not accounted for.

For this study, four potential confounding variables were included: GDP per capita, ${ }^{26}$ the proportion of the population ages $1-14,{ }^{27}$ the unemployment percentage, ${ }^{28}$ and the Economic Intelligence Unit's Democracy Index. ${ }^{29}$ Normalized indices for these confounding variables, by country, are given in Table Error! Main Document Only. in the footnote below. ${ }^{30}$

\section{Analytic Approach}

One approach to understanding the relationship between two variables, after accounting for one or more other variables, is the examination of partial correlations. Partial correlations are analogous to

${ }^{26}$ CIA WORLD FACTBOOK (online 2010), available at https://archive.org/stream/theciaworldfactb35830gut/35830.txt (last visited Sept. 23, 2014).

${ }^{27} I d$.

${ }^{28} I d$.

${ }^{29}$ Economist Intelligence Unit, The Economist, Democracy Index 2010, Democracy in Retreat, http://graphics.eiu.com/PDF/Democracy Index 2010 web.pdf (last visited Sept. 24, 2014).

${ }^{30}$ Table Error! Main Document Only.: Countries by Control Variables (Normalized 1-0)

\begin{tabular}{|c|c|c|c|c|c|c|c|c|c|c|c|c|c|c|c|c|c|c|c|c|c|c|c|c|c|c|}
\hline Country & 葍 & 獣 & 裹 & 悬 & 高 & 氞 & 圆 & 睘 & 园 & 漫 & 圆 & 圄 & 鳃 & 畧 & 불 & 罟 & 语 & 高 & 氛 & 煦 & 晹 & 㥸 & 影 & 呵 & 尌 & 圆 \\
\hline 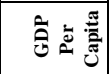 & 0.087 & 0.6538 & $0.6388 \mid$ & 0.087 & 0.0669 & 0.7258 & 0.0201 & 0.0351 & 0.1505 & 0.5351 & 0.0518 & 0.8278 & 0.0669 & 0.209 & 0.0452 & 0.3946 & 0.0033 & 0.0217 & 0.3679 & & - & 0.0435 & 0.1087 & 0.1221 & 0.1689 & 0.0067 \\
\hline 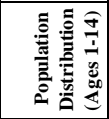 & 0.4164 & 0.2019 & 0.4322 & 0.2397 & 0.6562 & - & 0.5773 & 0.5016 & 0.2997 & 0.041 & 0.7508 & 0.4479 & 0.6562 & 0.6057 & 0.5205 & 0.9621 & 0.7729 & 0.7256 & 0.8139 & 0.0694 & 0.8991 & 0.7634 & $0.27 \mathrm{~B}$ & 0.3312 & 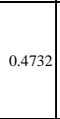 & \\
\hline 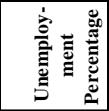 & 0.2574 & 0.1154 & $0.4083 \mid$ & 0.0917 & 0.2515 & 0.0917 & 0.284 & 0.1746 & $0.3964 \mid$ & 0.1154 & 0.3609 & 0.0296 & 0.8521 & 0.068 & 0.2544 & 0.4083 & 0.4083 & 0.1805 & 0.284 & \begin{tabular}{|l|}
0.0266 \\
\end{tabular} & 0.5178 & 0.2101 & - & 0.3787 & 0.3314 & \\
\hline 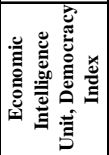 & 0.2168 & & 0.2236 & 0.1762 & 0.1667 & 0.5583 & 0.7371 & 0.6355 & 0.0136 & 0.8455 & 0.2575 & 0.2764 & 0.0136 & 0.5894 & 0.2642 & 0.1382 & 0.3672 & 0.5799 & - & $|0.5488|$ & 0.0786 & 0.0637 & 0.6382 & 0.1287 & 0.5271 & 0.1084 \\
\hline
\end{tabular}


regression coefficients in a multiple linear regression but can be more interpretable when the strength of a relationship is of primary importance. A partial correlation is interpreted similarly to a bivariate Pearson correlation except that the partial correlation indicates the strength of a relationship after the relationship of another (or several other) variable has been accounted for. In this study, the partial correlation of each freedom of information access variable with the LDPVC was examined, after controlling for the four confounding variables.

The relationships of each indicator of freedom of information access with the LDPVC were examined one at a time rather than simultaneously (as is often done in multiple regression analysis) for several reasons. First, the sample was very small and thus the statistical power was limited. Second, the freedom of information variables themselves were highly correlated. ${ }^{31}$ If the entire set of variables were examined simultaneously in a multiple linear regression, or analogous correlational model, then problems

31 Table 6: Bivariate Correlations among Indicators of Information Access

\begin{tabular}{|c|c|c|c|c|c|c|c|c|c|c|c|c|}
\hline & 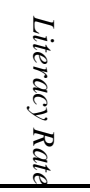 & 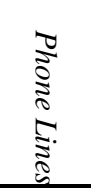 & $\begin{array}{l}2 \\
\stackrel{2}{2} \\
\frac{2}{2} \\
\frac{2}{8} \\
0\end{array}$ & 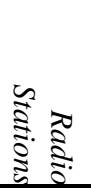 & 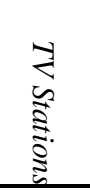 & 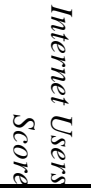 & 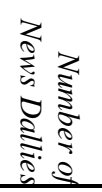 & $\begin{array}{l}3 \\
\vdots \\
0 \\
0 \\
0 \\
0\end{array}$ & 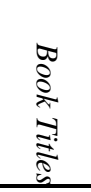 & 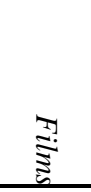 & 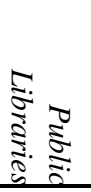 & 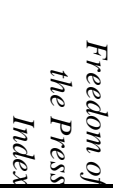 \\
\hline Literacy Rate & 1 & 0.633 & 0.543 & 0.453 & 0.469 & 0.607 & 0.315 & 0.557 & 0.502 & 0.38 & 0.317 & 0.325 \\
\hline Phone Lines & 0.633 & 1 & 0.54 & 0.251 & 0.477 & 0.771 & 0.523 & 0.59 & 0.704 & 0.737 & 0.314 & 0.326 \\
\hline Cell Phones & 0.543 & 0.54 & 1 & 0.258 & 0.56 & 0.587 & 0.32 & 0.375 & 0.345 & 0.429 & 0.015 & 0.181 \\
\hline $\begin{array}{l}\text { Radio } \\
\text { Stations }\end{array}$ & 0.453 & 0.251 & 0.258 & 1 & 0.281 & 0.488 & -0.014 & 0.135 & 0.252 & 0.073 & 0.599 & 0.379 \\
\hline TV Stations & 0.469 & 0.477 & 0.56 & 0.281 & 1 & 0.507 & 0.645 & 0.095 & 0.15 & 0.445 & 0.132 & 0.274 \\
\hline $\begin{array}{l}\text { Internet Users } \\
\text { Score }\end{array}$ & 0.607 & 0.771 & 0.587 & 0.488 & 0.507 & 1 & 0.383 & 0.695 & 0.779 & 0.578 & 0.416 & 0.438 \\
\hline $\begin{array}{l}\text { Number of } \\
\text { News Dallies }\end{array}$ & 0.315 & 0.523 & 0.32 & $\begin{array}{c}- \\
0.014\end{array}$ & 0.645 & 0.383 & 1 & 0.142 & 0.231 & 0.48 & 0.055 & 0.397 \\
\hline $\begin{array}{l}\text { Newspaper } \\
\text { Circulation }\end{array}$ & 0.557 & 0.59 & 0.375 & 0.135 & 0.095 & 0.695 & 0.142 & 1 & 0.878 & 0.59 & 0.162 & 0.554 \\
\hline Book Titles & 0.502 & 0.704 & 0.345 & 0.252 & 0.15 & 0.779 & 0.231 & 0.878 & 1 & 0.631 & 0.147 & 0.511 \\
\hline $\begin{array}{l}\text { Films } \\
\text { Produced }\end{array}$ & 0.38 & 0.737 & 0.429 & 0.073 & 0.445 & 0.578 & 0.48 & 0.59 & 0.631 & 1 & 0.061 & 0.569 \\
\hline $\begin{array}{l}\text { Public } \\
\text { Libraries }\end{array}$ & 0.317 & 0.314 & 0.015 & 0.599 & 0.132 & 0.416 & 0.055 & 0.162 & 0.147 & 0.061 & 1 & 0.282 \\
\hline $\begin{array}{l}\text { Freedom of } \\
\text { the Press } \\
\text { Index }\end{array}$ & 0.325 & 0.326 & 0.181 & 0.379 & 0.274 & 0.438 & 0.397 & 0.554 & 0.511 & 0.569 & 0.282 & 1 \\
\hline
\end{tabular}


of collinearity and multicollinearity would make coefficients unstable and inflate standard errors. In essence, both variables might appear unimportant if included in a model jointly because their shared relationship with each other might mask the effect each had with the LDPVC. On the other hand, examining relationships one at a time incurs the risk of assuming that one variable causes another when, truthfully, the variables may be related only through another variable not included in the estimation. In a correlational study, as presented here, however, causative claims are made cautiously, if at all. The goal is simply to examine the strength of relationships.

These relationships among variables are complex and interpretation will often be at the discretion of the analyst.

\section{Findings}

Visual examination using scatterplots of the relationships between the variables and the LDPVC suggest the presence of an outlier, Bahrain. Bahrain has unusual amounts of unrest given its access to information. This may be due to the fact that "The Sunni-led government has struggled to manage relations with its large Shia-majority population." ${ }^{32}$ Bahrain is a highly polarized society, with divided loyalties. Bahrain is also noteworthy because while it ranks first in cell phones, internet users, and number of news dailies, it rates much lower in such fundamental information variables as literacy, freedom of the press, book titles, movies produced, and public libraries (See Figure 4). In other words, except for newspapers (which lack freedom of the press), Bahrain's pre-cell phone and internet information environment is relatively weak. As a result of social polarization and the disparity of information variables, Bahrain was removed from the analyses. Indeed, Bahrain, illustrates what happens in the Market for Loyalties, when monopoly control is lost (as a result of new technologies)_-loyalty drops for the régime and new suppliers of identity may rush into the market.

\footnotetext{
${ }^{32}$ Bahrain, in CIA WORLD FACTBOOK (last updated June 23, 2014), at https://www.cia.gov/library/publications/the-world-factbook/geos/ba.html.
} 


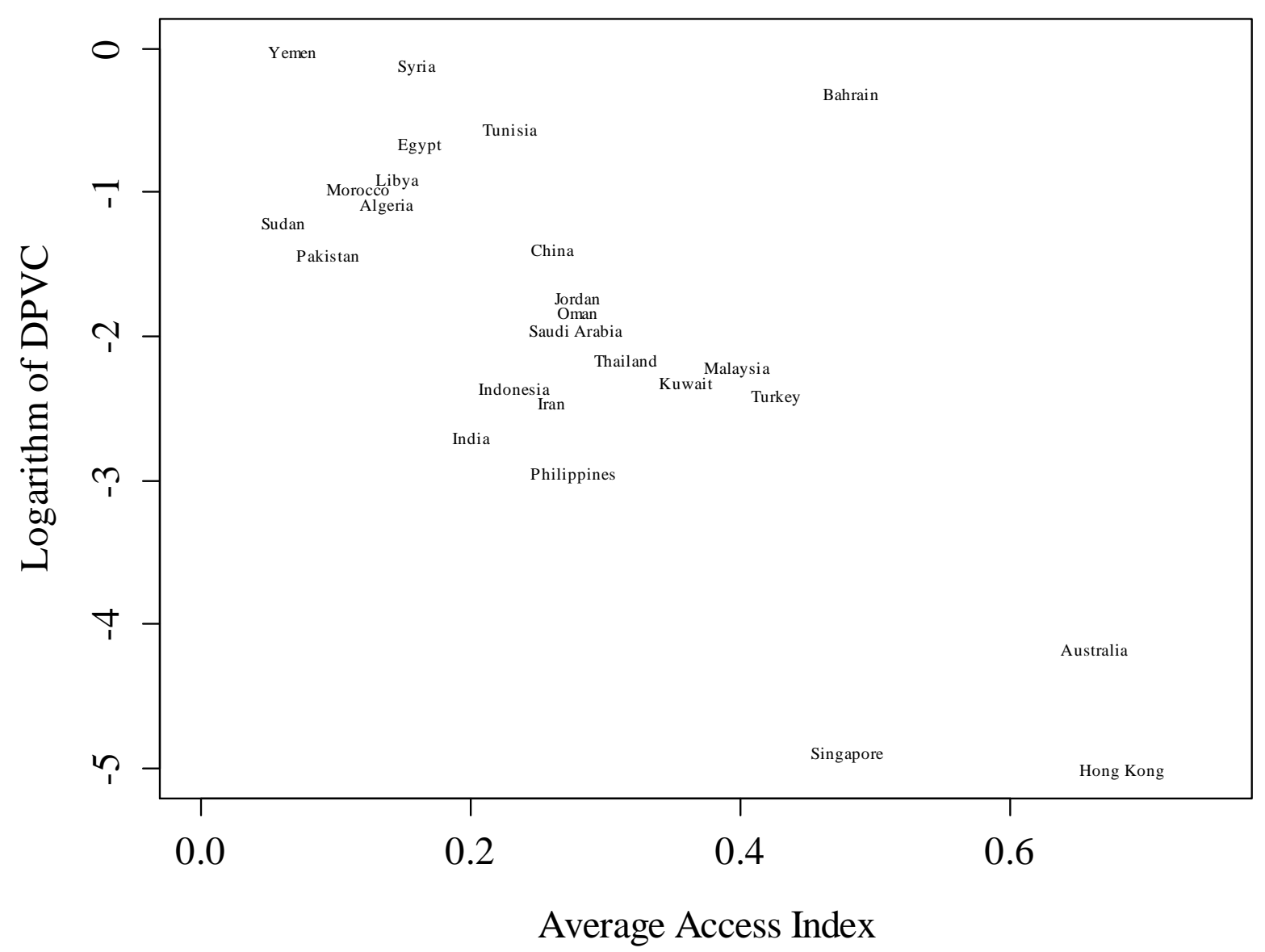

Figure 4: Studied countries charted by logarithm of the Demonstrations, Protest, Violence and Civil War (DPVC) Index against the Average Access Index, which measures information environment variables

For the remaining 25 countries, partial correlations with LDPVC, after controlling for the four confounding variables, as well as bivariate correlations with LDPVC, were found for each access variable and the average of the access variables. Because this sample is not random and represents a large proportion of all countries, p-values should be examined cautiously. It may be most appropriate, in fact, to focus on the size of the correlations rather than the p-values and limit inferences to the countries included in the study. As illustrated by Table 5, before adjusting for controls all access variables have 
moderate to large correlations with LDPVC, with the possible exception of the public libraries variable. ${ }^{33}$ After controlling for population age, unemployment, the democracy index, and GDP, at least four variables no longer have practically important correlations with LDPVC and all the correlations are smaller, as expected. Before adjusting for controls, all of the individual indicators of freedom of information access appear to have a moderate to strong relationship with LDPVC $(-.297<r<-.772)$. After adjusting for controls, about half the indicators continue to have at least a moderate relationship with the LDPVC $(r<-.200)$.

Particularly surprising is the Freedom of the Press index. This variable is nearly perfectly correlated $(r=.890)$ with one of the controls, the democracy index. The simple bivariate correlation of freedom of the press is large at $r=-.639$. However, the partial correlation after adjusting for controls has

ation Variables (with and without Controls)

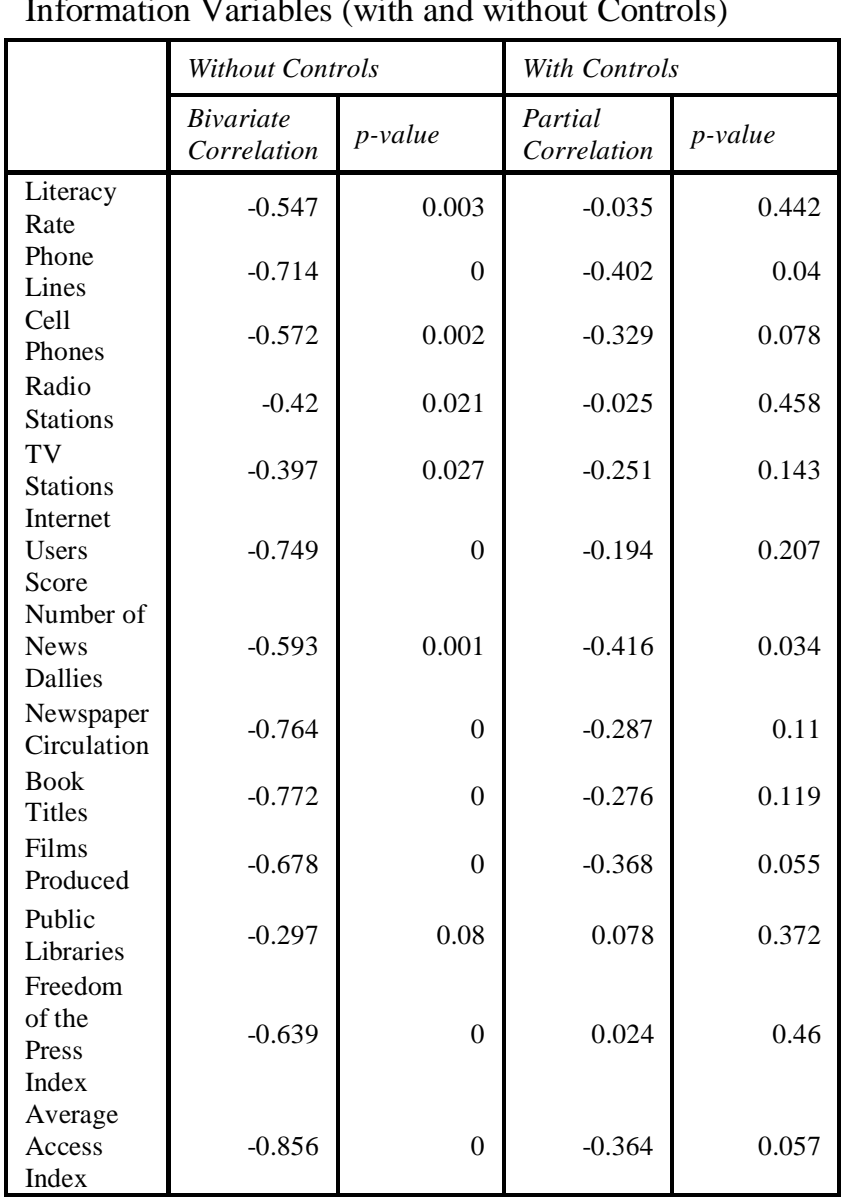


dropped nearly to zero $(r=.024)$. This is not surprising given the variable's high correlation with democracy. Interpretation, however, becomes problematic. The results simply suggest that, once a country's democratic index is accounted for, freedom of the press has no additional identifiable relationship with LDPVC. Within our studies there were no countries that were strong with respect to democracy and weak with respect to freedom of the press, or vice versa. Thus, it is difficult to separate the two constructs from each other. We simply can conclude that both variables are related to the LDPVC jointly. The other access variables in the model suffer from similar, though much weaker, relationships with the control variables. This high correlation between the Freedom of the Press Index and the Democracy index also impacts the partial correlation of the Average Access index with LDPVC. When a partial correlation is calculated that does not control for Democracy but does control for the other three confounding variables, we find a much stronger correlation of $r=-0.585(\mathrm{p}=0.003)$.

\section{Discussion}

Returning to Market for Loyalties theory, it predicts that states with greater freedom of information access should experience less destabilization as a result of events such as the Arab Spring. Specifically, the more new and substitute identities have been introduced into the Market for Loyalties, the more elastic the demand curve, until ultimately little disturbance is caused by the introduction of new identities. The assumption in this paper is the more diverse the information channels, the greater the number of identities introduced into the Market for Loyalties and the less shock from events, such as the immolations that touched off the Arab Spring. This study, however, measured destabilizing eventsdemonstrations, protests and violence-across an array of mostly Muslim countries. The findings of negative bivariate correlations (although weaker when controlling for GDP per capita, the proportion of the population ages 1-14, the unemployment percentage, and the Economic Intelligence Unit's Democracy Index) among what can be called the free access of information variables suggests that indeed environments with freer access to information have more elastic Market for Loyalties, and hence they are more stable. 


\section{Conclusion}

The conclusions that can be drawn from this non-random study of countries predominantly from the Muslim world are limited to that particular context, but they may be interpreted in light of Market for Loyalties Theory. It may be that the correlations would not manifest themselves in developed, Western countries, but according to Market for Loyalties Theory this would not be surprising if such countries had all attained relatively elastic identity demand curves.

It is also important to emphasize that the year of the Arab Spring was studied to highlight the destabilizing effects of the immolations across much of the Arab world. There were key event triggers that dramatically contributed to instability in many, if not most, of the Arab countries and some non-Arab Muslim countries as well. This means our study may be fairly context specific even when limited to the Arab world.

Besides studying Muslim countries, it would be interesting to study the developing world in general to see if states with restrictions on access to technology proved to be less stable in the face of events such as those that inflamed the Arab Spring. It would also be interesting to see if concepts such as loyalty, identity, and instability in the market could be more precisely identified and measured, adding further credence to Market for Loyalties Theory.

In the final analysis, what do we know? We know that there is moderate correlation between instability as measured by LDPVC and our freedom of information variables, after controlling for GDP per capita, population distribution, unemployment, and the Democracy Index. Furthermore, Market for Loyalties Theory can offer an interpretation of the data. Perhaps freedom of information does promote stability after all. This is significant because the theoretical and empirical evidence may be supporting 
our most fundamental democratic value—suggesting that freedom of information, including freedom of speech, is not just a moral imperative, ${ }^{34}$ but sound policy.

In the beginning of this paper, we asked, "Are non-democratic regimes 'better off' by monopolizing and controlling the flow of information over new information channels?" Very cautiously, we suggest that the answer, at least within our very limited and imperfect study, may be "no." We also asked, "Are democratic societies, particularly developing democracies, more stable when the flow of information over such channels is relatively unrestricted?" Again, qualifying our answer by admitting the limited nature of our study and the need for more research, we submit that the answer may be "yes." These are important questions, and it is the authors' sincere hope that others will take up this new inquiry for empirical and theoretical study.

34 "If there is any fixed star in our constitutional constellation, it is that no official, high or petty, can prescribe what shall be orthodox in politics, nationalism, religion, or other matters of opinion or force citizens to confess by word or act their faith therein." West Virginia State Bd. of Educ. v. Barnette, 319 U.S. 624, 642 (1943). See also United Nations, The Universal Declaration of Human Rights, art. 19, http://www.un.org/en/documents/udhr/ (last visited Dec. 9, 2013) (besides guaranteeing freedom of expression, guarantees freedom to "receive and impart information."). 